\section{Questión}

Periodismo / Comunicación ISSN 1669-6581
- Av. $44 \mathrm{~N}^{\circ} 676,1^{\circ}$ piso

CP 1900 - La Plata - Argentina

www.perio.unlp.edu.ar/question

Corea del Sur: un breve panorama general

Miguel Mendoza Padilla

DOI: https://doi.org/10.24215/16696581e324

\title{
Corea del Sur: un breve panorama general
}

\section{South Korea: a brief overview}

\author{
Miguel Mendoza Padilla / mendopadilla@gmail.com \\ Investigador, prof. en la UNLP, UNDAV y UNLAM en las carreras de comunicación social. \\ Integrante del IICOM FPyCS-UNLP. \\ Informe elaborado en base a información provista por Kim Kirock \\ (Jefe del Departamento de Operaciones de la comisaría SEUI CHUNGBU).
}

Esta pandemia ha puesto en crisis al sistema capitalista, colapsaron los sistemas de salud, barrieron con las economías y el comercio internacional. Ha puesto en observación las relaciones internacionales (relaciones humanas), se cerraron las fronteras no solo de países limítrofes sino también de provincias y municipios.

En muchos países la prioridad fue priorizar la salud por sobre la economía, las medidas apuntaron al aislamiento de la población por sobre el comercio. Entre esos países se encuentra Corea del Sur, unos de los primeros países después de la República Popular China en proteger a sus ciudadanos.

El plan fue llevado adelante por el gobierno a través de sus sistemas de salud y de seguridad para que la medida se cumpla y sea uno de los países con menos muertos e infectados. Hoy la cuarentena se ha levantado y la población lleva su barbijo. 


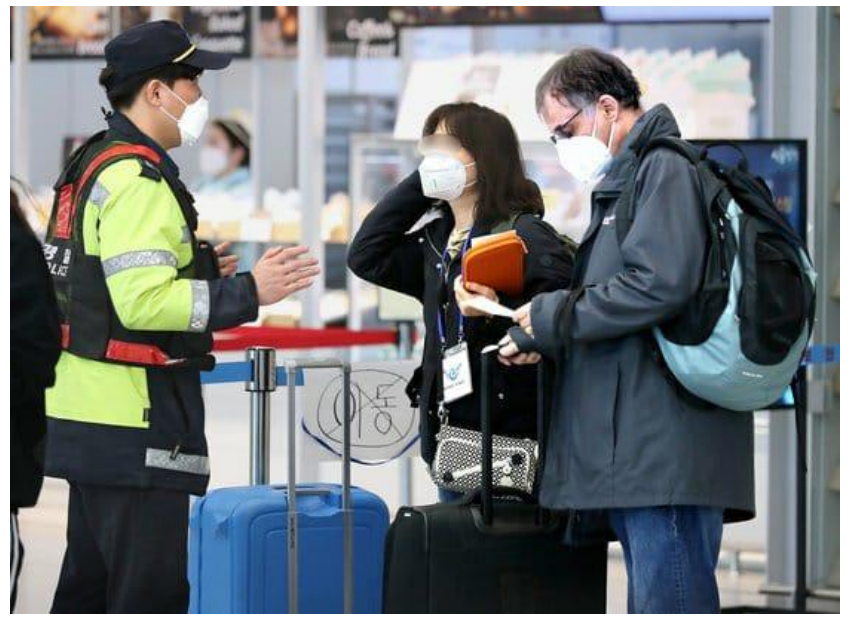

Aeropuertos

\section{Controles}

El plan se instrumentó a partir de un monitoreo y seguimiento de los casos que podían indicar que estaban infectados con el COVID19. Desde la detección que realiza la policía coreana en distintos puntos públicos (terminales de ómnibus y trenes, aeropuerto, etc.) se da aviso al Ministerio de Salud para que el mismo actúe y aísle a los infectados (se creó una aplicación para celulares para realizar un seguimiento de caso día a día).

Diariamente se realizan reuniones con expertos en salud y seguridad que realizan un monitoreo de la situación, ellos redactan un despacho que envían a los órganos del gobierno y a los medios de comunicación para que informen de la situación y cuáles son las medidas a tomar.

Por ejemplo, como medidas importantes que se tomaron fue el aislamiento de aquellos ciudadanos que regresaron a Corea después de decretada la cuarentena. Ahí ambos ministerios actuaron para llevar adelante el plan de control y monitorear a las personas. 


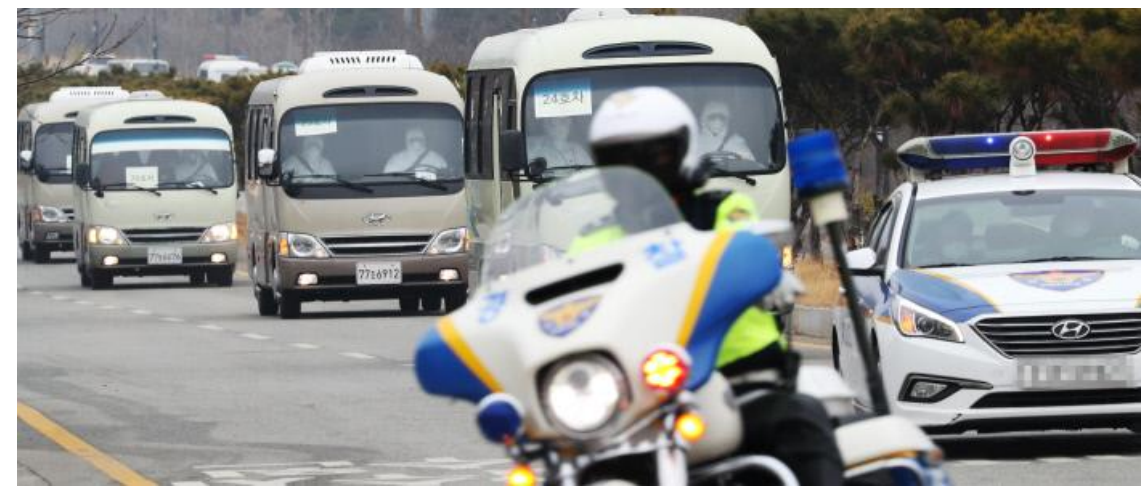

Caravana de traslados desde el Aeropuerto a los lugares de cuarentena.

Corea del Sur tiene, a través del Ministerio de Seguridad, un sistema de Circuito Cerrado de Televisión, cuyas cámaras están ubicadas en puntos neurálgicos desde los cuales se puede monitorear a la población. En situaciones de crisis se articulan trabajos conjuntos con los medios de comunicación para intercambiar imágenes, noticias, anuncios y delimitar la cantidad de periodistas y personal de los medios que realizan la cobertura en la vía pública.

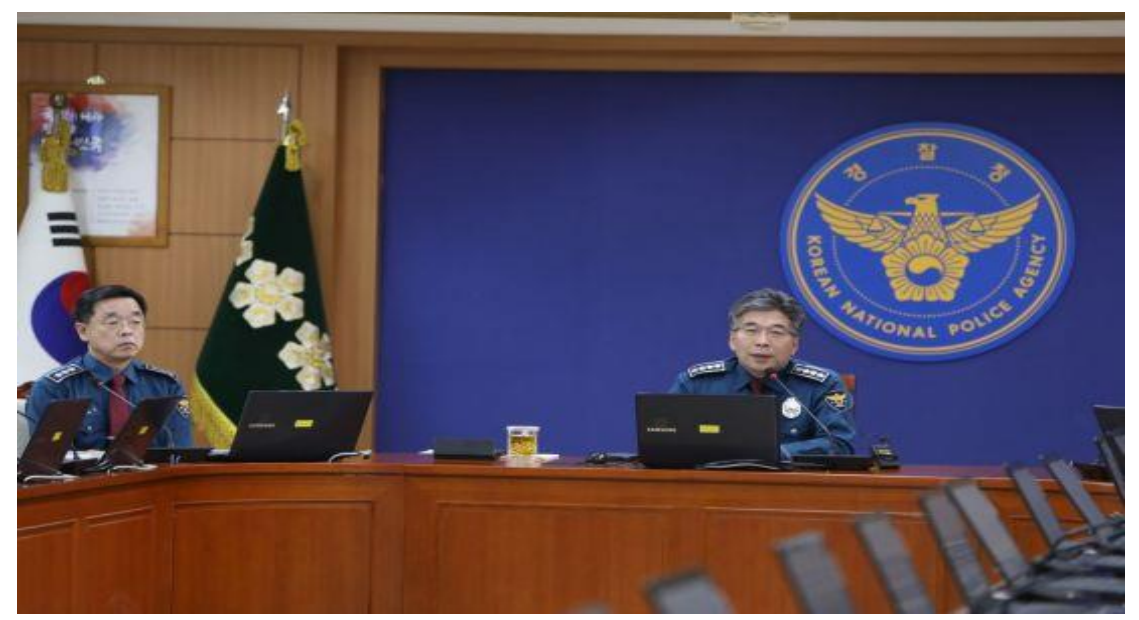

Jefe de la Policía Nacional, Comisario General Sr. Gabryong Min

Corea dispuso un comité de Coronavirus, para realizar un relevamiento de la pandemia y poder planificar cuales son las medidas a tomar en el día a día. 